\title{
Pedalling Out of Sociocultural Precariousness: Religious Conversions amongst the Hindu Dalits to Christianity in Nepal
}

\author{
Bishnu Pariyar ${ }^{1, *}$, Sushma Chhinal ${ }^{2}$, Shyamu Thapa Magar ${ }^{2}$ and Rozy Bisunke ${ }^{3}$ \\ 1 School of Geography, University of Leeds, Leeds LS2 9JT, UK \\ 2 Central Department of Anthropology, Tribhuvan University, Kirtipur 44618, Nepal; \\ sushmachhinal@gmail.com (S.C.); shyamut@gmail.com (S.T.M.) \\ 3 Samata Foundation, Lalitpur 44600, Nepal; rozy.bisunke@samatafoundation.org \\ * Correspondence: bishnu.pariyar@celp.org.uk
}

Citation: Pariyar, Bishnu, Sushma Chhinal, Shyamu Thapa Magar, and Rozy Bisunke. 2021. Pedalling Out of Sociocultural Precariousness: Religious Conversions amongst the Hindu Dalits to Christianity in Nepal. Religions 12: 856. https://doi.org/ $10.3390 /$ rel12100856

Academic Editor: Henri Gooren

Received: 26 August 2021

Accepted: 6 October 2021

Published: 12 October 2021

Publisher's Note: MDPI stays neutral with regard to jurisdictional claims in published maps and institutional affiliations.

Copyright: (c) 2021 by the authors. Licensee MDPI, Basel, Switzerland. This article is an open access article distributed under the terms and conditions of the Creative Commons Attribution (CC BY) license (https:/ / creativecommons.org/licenses/by/ $4.0 /)$.

\begin{abstract}
Christian conversion has become a major topic of discussion amongst academics, religious leaders, and policymakers alike in recent decades, especially in developing countries. Nepal has witnessed one of the highest rates of Hinduism to Christianity conversion in South Asia. Whilst there are no legal restrictions for religious conversion in Nepal, the conversion from Hinduism to Christianity appears to be disproportionately higher amongst Dalit communities in Nepal. However, religious conversion amongst Nepalese Dalits is yet to be fully understood. This research uses mixed methodologies of data collection and analysis to explore various issues related to religious conversion amongst Hindu Dalits into Christianity in Nepal. Results indicate whilst elderly and female Dalits tended to convert to Christianity, a range of factors specific to personal and communal biographies including social, cultural, emotional, and spiritual interplay together to shape the process of religious conversion amongst the Dalits. The paper concludes that the study of religious conversion should consider a range of sociocultural factors to fully understand the dynamics of religious conversion amongst Dalits.
\end{abstract}

Keywords: religious conversion; Dalits; discrimination; Christianity; Nepal

\section{Introduction}

Religious conversion is a process by which a person commits to the beliefs of a new religious tradition and shifts away from their previously held religious beliefs (Stark and Finke 2000). Whilst religious conversions take place mainly for spiritual reasons, a range of other personal and sociocultural factors also underpin such conversions (Parrucci 1968; Cartledge 2013; Doron and Broom 2013; Stronge et al. 2021). Political changes in a country's history and religious freedom tend to play a role in accelerating modernisation and social changes such as religious conversion (Wankhede 2009; Falla 2001; Turner 2013; Fernandes 2011). The abolition of Hindu monarchy and declaration of a secular republic in an overwhelmingly Hindu country Nepal in 2008 has brought the thorny issue of religion to the forefront of political debate amongst political parties, civil society, and religious institutions (Fricke 2008; Letizia 2012). Along with state restructuring and inclusive polity, secularism and republicanism constituted two key demands of the Maoists, who waged a decade-long civil war in Nepal causing more than 17 thousand deaths and the destruction of infrastructures costing billions in the poverty-stricken country. Whilst meeting Maoists' demands ended the civil war, religious conversion in general and conversion to Christianity in particular began to rise dramatically following the declaration of a secular state in Nepal. Published statistics demonstrate that the Christian population grew exponentially from 10, 200 in 2001 to almost 400,000 (1.4 per cent), with much growth taking place after the declaration of a secular state in Nepal (Central Bureau of Statistics 2001, 2011). Many scholars argue that Nepal's government census underreports the Christian population, and Nepal's Christian population is growing at 10.9 per cent annually since 1970; the current 
figure could be as high as 3 million (10 per cent) of Nepal's population (Gordon-Conwell Theological Seminary 2013). Some projections suggest that between four and eight per cent of the population of Nepal has converted to Christianity in the last two decades alone (Fricke 2008). In Nepal and elsewhere, religions are inherently associated with local and national politics and identity. As such, some political parties such as the Rastriya Prajatantra Party (RPP) and other Hindu organizations in Nepal have demanded a Hindu state and the restoration of Hindu kingdom (Doja 2000).

Religious proselytization is understood as an act of enticing or providing conditions for inviting or persuading individuals for an involuntary forced conversion of people's religious faith through unfair means such as bribery, coercion, or violence, considered illegal in many countries (Fountain 2015). Despite proselytization being considered illegal in Nepal, conversion from Hinduism to Christianity appears to be disproportionately higher amongst the Dalit communities, accounting for more than 65 per cent of Nepalese Christians (Pattison 2018; Dhakal 2014). Data from India also indicate that between 60 to 70 per cent of Indian Christians have Dalit roots, and around 15 to 20 per cent are of tribal origin (Robinson and Kujur 2010). Studies on religious conversions globally such as Africa (Villa-Vicencio and Grassow 2009; Beidelman 1982), Asia (Flemming 2019; Lorenzen 2003; Griffiths 2003; Lamb and Bryant 1999; Romain 2000) and Latin America (Racine 2008; Cruz 2014; Apichella 1996) provide ample evidence of religious conversion into Christianity raising global Christian population from 31.5 per cent in 2010 to 33 per cent in 2018-19 (Anderson 2004). In addition, the growth of Christianity in Nepal should be considered as a part of this global trend. However, the existence of a widespread precarious socioeconomic status (poverty $-48 \%$; literacy $-40 \%$; chronic childhood malnutrition $-60 \%$; food deficiency - 85\%; and life expectancy— 48 years (Central Bureau of Statistics 2011)) and a disproportionally higher rate of religious conversion amongst Hindu Dalits have opened up the debate if Dalits have been enticed and influenced inappropriately to sell religion for money in exchange for conversion into Christianity through the activities of foreign missionaries (Gibson 2019). In addition, a sudden and dramatic rise in the economic status of many church leaders in Nepal has led to the suspicion that they might have unduly influenced Dalits and indigenous communities towards religious conversion in exchange for monetary and material incentives (Campbell 2016).

Whilst a milieu of personal emotional and psychological, sociocultural, and economic factors interplay in a myriad of complex ways, financial and material incentives cannot solely explain the process of religious conversion (Rambo 1993). Previous studies on religious conversion in Nepal reported that religious conversions were mainly connected with health, healing, and educational opportunity (Cartledge 2013; Doron and Broom 2013). As religion is considered a journey of peace, joy, good health (healing), security, prosperity, and eternity amongst other things, an attempt to understand religious conversion should be understood as a part of broader transformative social-political process (Grudem 1994; Foucault 2002).

Whilst the narratives of proselytization reflect the views of non-Dalits higher castesindividuals and institutions who are primarily Hindus (Saiya and Manchanda 2020; Peace 2004) - previous research on Christian conversion in Nepal indicates that neither were the converts enticed by the promise of economic prosperity nor did those newly converted Christians including members of the Dalit community improved their economic status as a direct result of conversion to Christianity (Upadhyay 2020; Rai 2017). This paper neither makes any assumptions about religious conversion in Nepal nor does it naturally deducts that the disproportionally high rate of Christian conversion amongst the Dalits is a direct result of an active proselytization taking place in Nepal. This leaves the debate on religious conversion in Nepal, especially the conversion of Hindu Dalits to Christianity in need of further exploration and explanation, as it appears to be a part of the broader societal changes encompassing of an individual's life experiences, exercise of individual freedom, and adaptation of modernity (Jindra 2014; Richardson 1985; Hood et al. 2018; Zinnbauer 
and Pargament 1998). As such, this paper uses a social theory framework to investigate the phenomenon of Christian conversion of the Dalits in Nepal.

This paper investigates the issue of religious conversion amongst the Hindu Dalits to Christianity within sociocultural institutions and action situations. In doing so, it explores a range of push factors in Hinduism and pull factors in Christianity, which are contributing to religious conversions amongst the Dalits in Nepal. The paper is structured as follows: Section 1 introduces the issues of religious conversion in Nepal, whilst a theoretical framework for the paper is presented in Section 2. Section 3 provides an overview of the development of Christianity in Nepal. The research methods, sample characteristics, and analytical approach used in the paper are given in Section 4. Results and analysis are provided in Section 5. The conclusions of the paper are presented in Section 6.

\section{Overview of Social Theory of Religious Conversion}

Although the study of religious conversion came to prominence in the heyday of the New Religious Movements, especially in the 1970s and 1980s, the process of religious conversion is not a new phenomenon, dating back to the early twentieth century, especially during the colonisation period when many parts of the world were ruled by the Europeans (Zinnbauer and Pargament 1998). The recent resurgence in religious conversion in terms of both academic discourse and practice has begun to recognize it as a significant process in human socialization (Snow and Machalek 1984). Despite the development of a considerable volume of scholarship and global growth in religious conversion, especially to Christianity, there is little agreement on what constitutes religious conversion and the factors that facilitate and constraint such conversions (Long and Hadden 1983; Thumma 1991). As such, the complex mosaic of religious conversion can only be understood and explained fully by broadening its notion to encompass a range of socioeconomic contexts in which religious activities are nested upon and cases of radical changes whereby individuals seek to alter their biographies, perspectives, and identities in a variety of settings in which such conversions take place (Greil and Rudy 1983; Paloutzian et al. 1999).

Literature on religious conversion can be broadly categorised into three schools of thought, namely brainwashing, personal identity, and sociopsychological tipping point. Firstly, proponents of the brainwashing hypothesis argue that individuals experiencing traumatic life events are vulnerable and susceptible to falling into the hands of 'master manipulators' who would brainstorm them to religious conversion (Singer and Lalich 1995). For example, the rise of cult groups and religious fundamentalism and religious orthodoxy radicalise potential converts to abandon their current religious affiliation and show legion to new religion as a way of overcoming traumatic life experiences. However, the brainwashing hypothesis has come under attack in recent decades because significant decision such as religious conversion is considered to be an individual decision, which can be influenced by individual's unique circumstance but not deterministically altered by so-called manipulators, although they may cause the radicalisation. As such, religious conversion should explore a range of both individual and societal issues including sociocultural, economic, political, and psychological aspects to fully understand why people with good jobs, homes, and families might want to give up such lives to become members of a communal religious movement and ultimately convert to another religion (Barker 1984). Apologists such as McGrath (2012), who was an aggressive atheist himself previously, argue that an effective communication of Christian ideas, values, and faith enable non-Christians and nonbelievers to expand their reasoning and imagination by engaging with Christianity. In doing so, the even the nonbelievers slowly begin to find meaning to their life by engaging in a deeper richness of understanding of the Christian faith.

Secondly, proponents of the 'personal identity theory' argue that religious conversion should be understood as the process of altering an individual's biography and life history, which is a result of symbolic interactions with religious institutional arrangements and their surroundings (Travisano 1970). Failure to provide enough attachment and sense of 
belonging by an individual's current religious faith causing apathy and 'identity crisis' act as a catalyst in the process of religious conversion as individuals seek to resolve their identity problems (Bankston et al. 1981). In doing so, individuals seek to redefine their situations in religious terms and create a world of fresh religious beliefs and reinterpretation of self-identity by seeking to reorient themselves towards new religions through religious conversion (Beckford 1997). A growing body of literature argues that individuals seek to create their own psychoanthropological realm through hermeneutic explorations of religion and faith (McCullough and Willoughby 2009; Newton and McIntosh 2013; Hindmarsh 2014). Such explorations often enable individuals to bring a sense of purpose and new meanings to their existence by way of adoption of a new faith through religious conversions (Oviedo 2019).

Similarly, Peck (1987) argues that newly assumed religious identity not only provides them moral solace but builds connections between religious faith and futuristic hope through the intervention of God. In doing so, the newly converted often draw parallels about their own experience and biographies and many of those historical biblical figures (Maruna et al. 2006). The positive role that the church groups provided through acceptance and welcoming and forgiveness about an individual's previous religious experience provide an impetus for religious conversion. Furthermore, individuals' particular circumstances coupled with institutional and procedural easiness in converting play an enabling role for the converts to assume and sustain personal identity. Richards (1978) posits that the church community and missionaries often encourage and emphasize an ideological shift, arguing that sustaining ideologies are crucial to the survival of religious identity in extreme situations (Skotnicki 1996; Timor 1998).

Thirdly, traumatic experiences encountered by individuals in their current religious affiliation inflict them with long-term sociopsychological impacts, which act as a tipping point for them to seek alternative religious identity. The proponents of the sociopsychological tipping point argue that individuals flounder amongst various religious alternatives and are characterized by openness to a variety of religious views. The 'seven stages model' of religious conversion proposed by Lofland and Stark (1965) argues that consideration of individuals' biographical and sociocultural disposition is crucial in understanding the process of religious conversion amongst them. As such, they contend that individuals experience enduring and acute tensions from their current religious faith and consider religion as not only the source of their problems but also an exit option as a problem-solving mechanism (Sykes 2021). Upon reaching a tipping point and exhaustion of coping strength due to rising apathy towards their religion, individuals seek alternative religious affiliation and affirm bonds to the individuals from another religious background (Goffman 1968). The intensive interactions between the potential converts and other individuals from what would be his/her new religion leads to a complete dissociation from current religious faith and declaration of a legion to the new religion affiliation to restore their lost socioreligious status (Mead 1967; Heffernan 2019).

\section{Historical Overview of Christianity in Nepal}

Historical evidence suggests that the first Christian missionary to set foot in Nepal was a Portuguese Jesuit Father named Juan Cabral, who arrived in Kathmandu Valley in 1628 (Sharma 2001). The ruling king Laxmi Narsingh Malla conferred him with Tamrapatra (Copper Plate), allowing him to preach Christianity in Nepal. A short visit by two European missionaries named Albert d'Orville (Belgian) and Johann Grueber (Austrian) in 1661 to Nepal marked another milestone in the history of Christianity in Nepal (Barclay 2009). The Vatican in Rome sent Capuchin Fathers to set up a permanent mission station in Kathmandu in 1715 during the reign of King Ranajit Malla. The Capuchin Fathers preached Christianity in Patan and Bhaktapur areas for more than half a century until they were banned by King Prithvi Narayan Shah upon conquering the Malla kingdoms of the Kathmandu Valley in 1769 (Alsop 1996). 
Whilst the Malla kings of the Valley welcomed Christian missionaries, the state prosecution of Christians began in Nepal with the beginning of the Shah Dynasty in the Valley, as King Prithvi Narayan Shah expelled more than 57 newly converted Christian Newars from Nepal to Bettiah (India) and banned other religions except for Hinduism (Landon 1928). However, a small number of Evangelists of Nepali origin in India (Darjeeling) were able to enter Nepal surreptitiously to preach Christianity. As the world war began in 1914, the first ordained pastor of Nepali origin Ganga Prasad Pradhan came to Kathmandu with his forty followers from Darjeeling to preach Christianity mainly through Bible translation and other evangelistic advocacy (Alsop 1996). However, upon finding out their presence in Kathmandu, the state ordered them to leave the country immediately, saying, 'there is no room for Christians in Nepal' (Perry 1990, p. 34).

The fall of the oligarch Rana rule and introduction of democracy in 1950 marked some degree of religious freedom in Nepal, and King Tribhuvan appealed to foreign organisations including Christian missionaries to assist Nepal in development activities. However, the Christian missionaries were given a limited scope and were mainly supporting Nepal in health and education sectors through United Mission to Nepal (UMN). Mission hospitals in Tansen (Palpa), Bhaktapur, and Ampipal (Gorkha) and schools such as St. Xavier's and St. Mary's Schools in Jawalakhel (Lalitpur) and Amar Jyoti Secondary School in Luintel (Gorkha) were established by Christian missionaries. Whilst there were virtually no Christians in Nepal before 1951, Christianity slowly spread in Nepal expanding its population to 458 in 1961. As the work of the Christian missionaries intensified in Nepal, the Christian population grew steadily throughout the 1970s and 1980s during the Panchayat era. As people's movement gained momentum against the Panchayat rule, people's freedom was curtailed, including religious freedom; Christians were prosecuted, and many church leaders were jailed or fled the country in the 1980s.

The introduction of multiparty democracy in 1990 ushered a new era for democratic freedom including religious freedom, which led to increased activities of the Christian missionaries, and the Christian population increased steadily, reaching 10, 200 in 2001 (Central Bureau of Statistics 2001). The end of a 10-year-long Maoist war, overthrowing of constitutional Hindu monarchy, and establishment of a secular state in 2008 marked another milestone in religious freedom in Nepal. The Christian population grew exponentially, reaching 375,699 (1.4 per cent) of the country's population by 2011 (Central Bureau of Statistics 2011), making Nepal one of the countries with the fastest-growing Christianity, with 10.9 per cent annual growth since 1970 (United States Department 2018). Christmas is included as one of the public holidays in Nepal owing to a significant rise in the Nepalese Christian population. Whilst proselytise and forced conversions are considered legally punishable, the Christian population continues to grow rapidly in Nepal. It is widely claimed that the population of non-Hindu are systematically underreported in Nepalese censuses, with many observers estimating Nepal's Christian population as 1 million (FNCN 2012) and some even estimating it around 3 million (10 per cent) of the population (Gordon-Conwell Theological Seminary 2013).

\section{Materials and Methods}

\subsection{Study Site}

This study was carried out in the Ghorahi area of Dang in the midwestern area of Nepal. Ghorahi lies in the catchment of the River Babai within the Chure Range in the inner Terai area of Nepal. As such, Ghorahi Valley is characterized by fertile land, which is suitable for agriculture. Ghorahi City was declared a submetropolitan city during the state restructuring process in 2015. It is situated about $23 \mathrm{~km}$ northwest from the neighbouring town of Lamahi, which is situated along the east-west Mahendra Highway. Ghorahi Valley has a relatively accessible landscape, mainly due to its connectivity with towns and cities in the neighbouring districts including Salyan, Pyuthan, Banke, Surkhet, Arghakhanchi, and Rolpa. It also has good transport facilities, which has made travelling easier for the residents including those attending churches and Christian missionaries. As it is a city area, 
about 60-70 per cent of the houses in the area are built from cement, whilst the remaining 30-40 per cent of the houses are made from locally available materials such as straw, mud, bamboo, wood, and mud, amongst others. Figure 1 below shows the map of the study area. Administratively, Ghorahi is the headquarter of the Dang District, where most of the government offices, schools, colleges, health posts, hospitals, and camps of security agencies such as Nepal Police, Nepal Army, and Armed Police Force are also situated in the area.

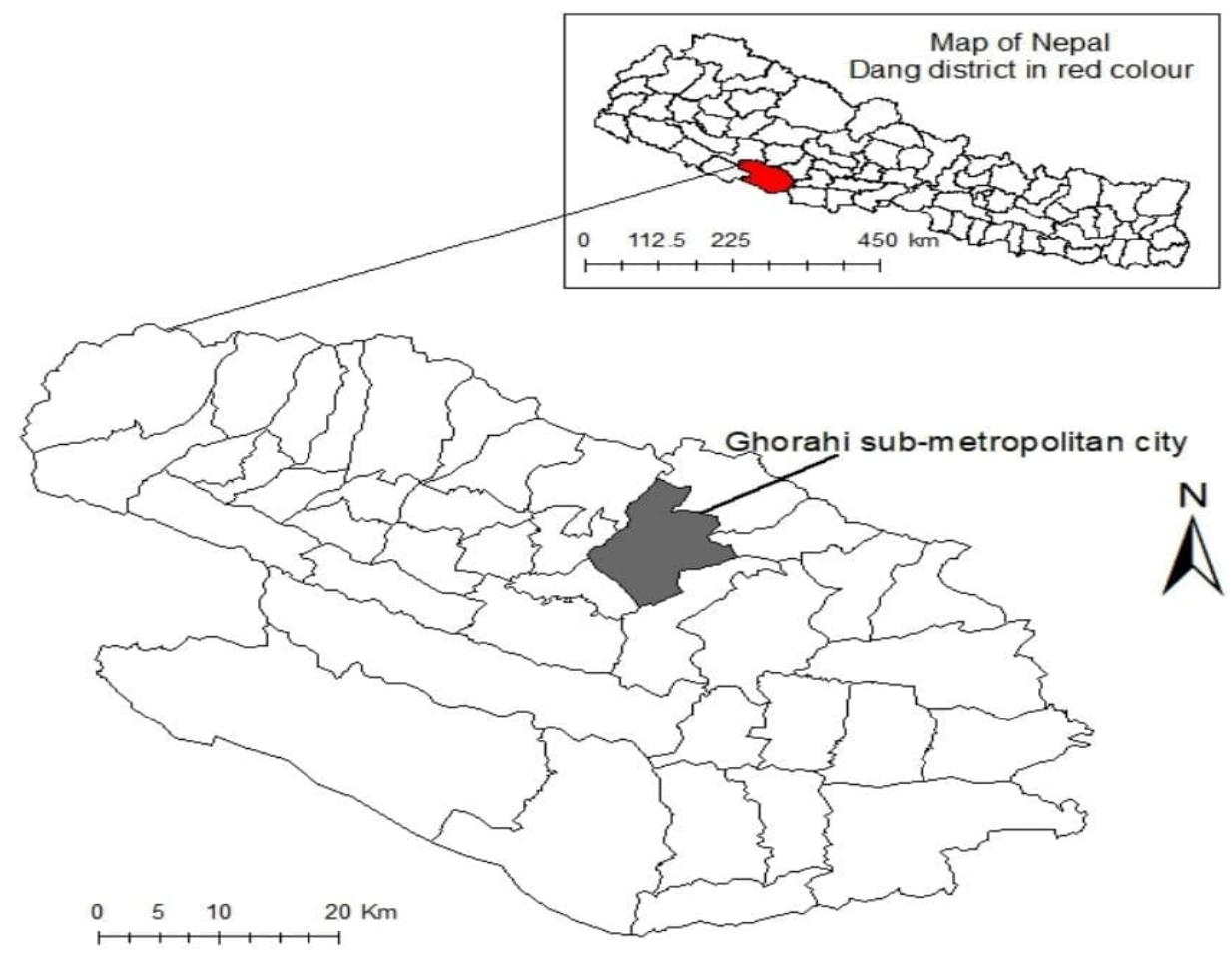

Figure 1. Map of the Study Area.

Demographically, Ghorahi is a multicultural city, where people from different communities including Brahmin, Chhetri, Newar, Magar, Gurung, Tharu, Muslim, Kami, Damai, Sarki, Badi, and Sanyasi) live. Historically, Dang District was ruled by the Tharu Dynasty and was ruled by a Tharu king Dangisaran before King Prithvi Narayan Shah united the country. Dang District is still endowed with rich Tharu culture, tradition, and language. Ghorahi is a significant place for migration because of road access and easy travel from neighbouring districts, which has considerably increased the population of the city. The settlement pattern within the city demonstrates distinct clustering of caste and ethnicity in the area. Newari communities, who are mostly involved in business, reside in the central area of the city, whereas historically oppressed Badi and Damai communities live on the western side of the city. Similarly, Magar communities are located on the north side of the city, and other communities such as Tharu, Chhetri, and Brahmins live on the southwestern part of the city along the bank of the Babai River. Whilst the settlement patterns in Ghorahi represent a clear communal clustering, the centre part of the city remains home to people from different castes, increasing interactions amongst people following different religions and observing different culture and traditions. As such, the multicultural population of Ghorahi provided a unique opportunity to investigate the interactions of people from different faiths.

Published statistics indicate that the total population of Ghorahi Valley is 156,164 people. A significant proportion of the population (63 per cent) are involved in agriculture, whereas the remaining 37 per cent of people are involved in nonagricultural sectors such as government services, police, armed forces, business, teaching, and several other technical professions including doctors and engineers (Ghorahi Municipality 2018). As 
a fast-growing city, Ghorahi has seen rapid industrialization in recent years. Published statistics show, altogether, 2356 small and big industries with two big cement factories in operation in the area. Furthermore, Ghorahi has 86 industries, which employ more than 10 workers (Ghorahi Municipality 2018).

Similarly, the district of Dang has relatively better educational facilities compared to other neighbouring districts. A total of 602 schools are in operation in the district, of which 424 schools are government schools, whilst the remaining 178 are private schools. Despite having good access to education in the area, only 74 per cent of the primary school enrolments are admitted to higher education, and only 11.2 per cent of them complete their higher education, which is significantly higher amongst the Dalits communities in the area (DDC 2018).

\subsection{Research Methods}

Data for this research was collected through key informant interviews and focus group discussions. A total of five focus group discussions were held in four church groups in Ghorahi City, namely Pratapi Church, Susamachar Church, Balidan Church, Anugrahan Church, and Jyoti Church. A total of 41 key informant interviews were also carried out as a part of this research. A snowball sampling method was used to recruit participants living and working in Ghorahi. Four eligibility criteria were used for recruiting participants: Dalit castes; Christians; age at least 18 years; and residency, living in Ghorahi either temporarily or permanently. In order to obtain representative data, the participants were recruited from different age groups such as 15-25 years, $26-40$ years, and above 40 years, as it was crucial to collect data on informants' experience of religious conversion across different age groups. Table 1 presents the characteristics of the research participants.

Table 1. Characteristics of the Sample.

\begin{tabular}{|c|c|c|c|c|c|c|c|}
\hline \multirow[t]{2}{*}{ Categories } & \multirow[b]{2}{*}{$\begin{array}{c}\text { Key } \\
\text { Informants }\end{array}$} & \multicolumn{6}{|c|}{ Number and Location of Key Informant Interviews and Focus Group Discussions } \\
\hline & & $\begin{array}{l}\text { Informants/ } \\
\text { Kuragraphy }\end{array}$ & Focus Group & Discussions & & & \\
\hline & & & $\begin{array}{l}\text { Pratapi } \\
\text { Church } \\
\text { (Bharatpur) }\end{array}$ & $\begin{array}{l}\text { Ghorahi } \\
\text { Susamachar } \\
\text { Church } \\
\text { (Rajhena) }\end{array}$ & $\begin{array}{l}\text { Balidaan } \\
\text { Church } \\
\text { (Lohasur) }\end{array}$ & $\begin{array}{l}\text { Anugraha } \\
\text { Church } \\
\text { (Rangara) }\end{array}$ & $\begin{array}{c}\text { Jyoti Church } \\
\text { (Shewar } \\
\text { Khola) }\end{array}$ \\
\hline \multicolumn{8}{|l|}{ Gender } \\
\hline Male & 6 & 15 & 3 & 3 & 3 & 3 & 3 \\
\hline Female & 4 & 26 & 6 & 5 & 5 & 5 & 5 \\
\hline \multicolumn{8}{|l|}{ Caste } \\
\hline Dalits & 10 & 41 & 9 & 8 & 8 & 8 & 8 \\
\hline \multicolumn{8}{|l|}{ Occupation } \\
\hline Traditional occupation & 2 & 7 & 3 & 3 & 0 & 1 & 0 \\
\hline Housewife & 3 & 13 & 3 & 1 & 3 & 2 & 4 \\
\hline Daily wage labour & & 8 & 0 & 1 & 4 & 1 & 2 \\
\hline Student & 1 & 3 & 1 & 0 & 1 & 1 & 0 \\
\hline Businessman & 1 & 3 & 1 & 0 & 0 & 2 & 0 \\
\hline Pastor & 1 & 5 & 1 & 2 & 0 & 1 & 1 \\
\hline Government Officer & 1 & 1 & 0 & 1 & 0 & 0 & 0 \\
\hline Teacher & 1 & 1 & 0 & 0 & 0 & 0 & 1 \\
\hline \multicolumn{8}{|l|}{ Marital status } \\
\hline Married & 5 & 26 & 9 & 3 & 4 & 5 & 5 \\
\hline Unmarried & 2 & 6 & 0 & 1 & 2 & 2 & 1 \\
\hline Intercaste married & 1 & 6 & 0 & 2 & 1 & 1 & 2 \\
\hline Widow & 2 & 3 & 0 & 2 & 1 & 0 & 0 \\
\hline \multicolumn{8}{|l|}{ Level of Education } \\
\hline Illiterate & 1 & 11 & 2 & 3 & 3 & 2 & 1 \\
\hline School Level & 5 & 11 & 2 & 3 & 2 & 2 & 2 \\
\hline College Level & 4 & 19 & 5 & 2 & 3 & 4 & 5 \\
\hline Total & 10 & 41 & 9 & 8 & 8 & 8 & 8 \\
\hline
\end{tabular}


In total, ten participants representing various Dalit castes including Damai, Kami, Sarki, and Badi took part in the key informant interviews, of whom six were male and four were female. The age range of the participants was 18-74. Similarly, five participants were married, two were unmarried, one had intercaste marriage, and two were widows.

A total of five key focus group discussions were held in five settlement areas of Ghorahi City, where forty-one participants took part in the research. All the respondents belonged to the Dalit castes. Twenty-six participants were female, and fifteen were male. Participants had different marital statuses: twenty-six were married, six were unmarried, and six had intercaste marriage, whilst three participants were unmarried. Similarly, research participants came from diverse professional backgrounds such as agriculture, business, teaching, pastoring, housewife, civil service, and wage labour. Generally, some of the participants belonging to the Pariyar caste, who were financially well off, had set up tailoring businesses, whilst those who did not have the financial capability worked as custom sewers in tailoring shops. Bishwokarma (Kaami) had set up jewellery shops and worked as goldsmiths, whilst participants belonging to Nepali (Sarki) worked as cobblers. Members of the Badi community were mostly singers and dancers who previously worked as prostitutes. Dalit castes such as Pariyar, Bishwokarma, and Nepali are called also Damai, Kaami, and Sarki, respectively, although the use of such terms is not preferred by Dalit castes mainly due to the stigma attached with them. Higher castes such as Brahmin and Chhetri were involved in civil service, whilst Newars were mostly involved in the business. Ethnic communities such as Chaudhari were mostly worked as domestic workers and cropsharing farmers. The research site was still characterised by the prevalence of illiteracy, as eleven participants were illiterate, eleven were educated to school level, and the remaining nineteen had college-level education. Ethnic groups such as Chaudhari and Newars spoke their ethnic languages as well as Nepali language, whilst participants from other castes spoke Nepali language.

Unlike previous studies on Dalits of Nepal (Bishwakarma 2004; Parajuli 2007), this research included a broad mix of participants from various walks of life who have converted to Christianity including Dalit castes such as Damai, Kami, Sarki, and Badi. The rationale for including a mix of participants is due to the need to have a range of views given the complex nature of issues considered in this research, which included aspects such as religious conversion, sociocultural transition, and cultural identity. These are contested topics, as religious conversions are rapidly rising in Nepal, which has faced threats from Hindu fundamentalists in recent years. The mix of participants also enabled a rich and indepth understanding of the issues pertaining to religious conversion through exploration of Dalit experiences of converting to Christianity from Hinduism in Nepal and how such transitions have impacted their lives and livelihoods (Krueger 2014).

Focus groups are appropriate for obtaining rich contextual data, as they help to identify subjects' concerns and stimulate fresh ideas pertinent to research issues through debate and discussions, particularly when little is known at the outset (Hakim 2000). The focus group discussion was also an efficient means of determining the language people used when thinking and talking about their life experience as Christians in Nepal and the prevailing social and institutional settings that facilitated their conversion to Christianity (Krippendorff 2018). This helped to provide concentrated amounts of data in the participants' own words. The participants' interactions added richness to the data that might be missed in individual interviews or surveys and, more importantly, provided critical information for appreciating the social and cultural intricacies of the Dalit community both under Hinduism and Christianity. Focus group discussions also provided an opportunity for the researchers to interact directly with participants, facilitating discussions, probing responses, posing follow-up questions, and clarifying any dubious and contentious issues (Stewart and Shamdasani 2014; Foddy and Foddy 1994). Articulating opinions and presenting their arguments on important aspects such as state restructuring, citizenship, and constitution-making can be difficult for illiterate Dalits. The focus group method helped to avoid answers such as, "I do not know what to say". The rationale for choosing focus group 
discussions was also based on the necessity to stimulate research participants to build a clearer picture of the political and social fabric within which the notion of citizenship was visualised, claimed, and contested.

\section{Analysis and Discussions}

\subsection{Overcoming Sociocultural Discrimination}

The caste system is based on the "Hindu Pollution Concept" (Dumont 1980), which underpins many sociocultural aspects associated with the Hindu religion. Despite sharing many sociocultural practices including common deities, festivals, and rituals with higher caste non-Dalits, Nepalese Dalits continue to face a myriad of complex sociocultural disadvantages and discrimination linked to the violation of human rights, challenging values of human dignity, democracy, equality, and social justice (Bhattachan et al. 2003), as one respondent said:

[ ... Walking to the temple, singing, and dancing together during the ladies festival of Teej has no meaning; we were not allowed to enter inside the temple, we had to worship outside the temple. But once our family converted to Christianity, other fellow Christians do not treat us differently... ]

[Dalit Female, 55 years old]

Caste-based discrimination takes multiple forms including prohibition in temple entry, avoidance of food and water, restrictions on intercaste marriage, and untouchability, even though the constitution of Nepal declared Nepal as an 'untouchable-free' country (Gellner 2007), as another participant said:

[... 21 years old Dalit man and his other five friends were brutally murdered and thrown into a swelling river in Rukum District in western Nepal just for falling in love and attempting to marry a girl from higher caste... ]

[Dalit Male, 24 years old]

Discrimination and humiliation are experienced by Dalits in other aspects of their social and economic life such as renting rooms, purchasing land and houses, and setting up a business, as higher caste people avoid interactions particularly those with socioeconomic implications with Dalits due to religious-based taboos. Such experiences were reported by a number of research participants, as one of them said:

[ ... I was trying to buy land from a higher caste Brahmin to open a fresh house (meat shop). Instead of selling his land to me, a local higher caste Brahmin family sold it to another non-Dalit customer despite me offering competitive price because his high caste neighbour did not want me to set up a meat shop in his area as I was a Dalit, but I also had the money, mine was cash too... ]

[Dalit Male, 45 years old]

Higher caste individuals usually do not consume meat and meat-related products and cooked food prepared by Dalits. Whilst consumption of beef is totally forbidden amongst the Hindus, specific meat items such as pork and buffalo are not usually consumed by higher caste Brahmins and Chhetris. Opening of a meat shop by a Dalit to sell buffalo meat and pork was disapproved by the higher caste Brahmin, denying economic opportunity for a Dalit. Evidence from around the world demonstrates that granting more rights and opportunities, reducing inequalities, and tackling discrimination significantly contribute to social justice and economic development (Pariyar and Lovett 2016; Lawoti 2005; Lawoti and Hangen 2013). However, Dalits in Nepal continue to face a multitude of hindrances not only in terms of their inability to contribute to society but also to benefit from the community.

[ ... Under Hinduism, Dalits have become like deadweight as caste-based hierarchy constrains opportunity to play an active role in village sociocultural life. Upon conversion, I have become a pastor in the local church; our youths, girls, and women are also active 
in the church group. All Christians are children of Jesus Christ, the God. There is no caste amongst the Christians ... ]

[Dalit Male, 27 years old]

Furthermore, Dalits have been taking traditional occupations such as stitching clothes (Damai), jewellery- and utensil-making (Kami), shoe-making (Sarki), cleaning (Pode/Jyapu), dancing (Badi), street and sewage cleaning (Pode), singing (Gaine), and many other serviceoriented occupations, which are necessary for the everyday living of the individuals and communities. However, such traditional occupations are often considered to be Dalitspecific, low, and dirty jobs and are neither positively perceived nor fairly remunerated by the Hindu society. As such, the construction of collective identity amongst the Dalits in Nepal has largely been shaped by the need for resistance primarily against social segregation, cultural, and religious repressions including untouchability (Kharel 2010). Therefore, many respondents mentioned that avoidance of caste-based discrimination and improving their social and economic status has been one of the important aspects of Dalit movements in Nepal (Kisan 2005).

\subsection{Improving Gender Equality}

As with religious practices elsewhere, the Nepalese Hindu cultural practices are also nested upon and embedded within a complex network of historical relations maintained by a range of sociocultural factors including religion, which underpins human actions and interactions (Shellnutt 2017; Fricke 2008; Letizia 2012). The superimposed hierarchical structure of the Hindu religion has many traditional practices, which not only create gender inequalities but also perpetuate them. Many Hindu mythologies and religious texts explicitly mention that males hold superior positions compared to females in almost all aspects of human interactions including etiquette and conduct, food, and clothing amongst others (Cameron 1998). One of the informants said:

[ ... In this Hinduism, girls, and women are blamed for family misfortunes, and rights of girls and women are rarely taken seriously. We are considered just the characters to justify the reputation of the Hindu religion... . The world has moved on so much, but the Hindu religion has remained the same ... ]

[Dalit Female, 35 years old]

The existence of a complex web of sociocultural relationships, which are shaped by religious norms and traditions, contribute to the formation of gender inequalities and subordinate the role of women in society (Eriksen 2012; Klingorova and Havlíček 2015; Bawa 2019). The precarious position held by women in the Hindu religion was opined by a number of respondents, as one said:

[ ... After getting married, and before conversion from Hindu to Christianity when I came in my husband's house I had to address everyone respectfully even if they are younger than me, especially male members of my husband's family... ]

[Dalit Female, 40 years old]

Bennett (1985) argues that, akin to Hindus elsewhere, Nepalese Hindus also have different meanings and values attached to different physical changes to women's body such as puberty, menstruation, labour, and childbirth. Virgin girls are considered sacred living goddesses (kumari kanya) before menstruation. However, once girls have their first menstruation, they are devoid of their kumari kanya status. Furthermore, all the women are considered as impure and untouchable during menstruation irrespective of the caste, as one participant said:

[ ... We had to stay in cowsheds during menstruation because girls and women have periods because of the sin committed in the previous life. By living in the cowsheds we are cleansing ourselves from the sins. However, when we converted Christianity, there is nothing like that ... ] 
Hindu religion considers natural processes such as birth, puberty, and menstruation impure and attaches negative connotations with them, indicating predefined conceptions of the social position and role of women in society. Such hierarchical relation brings differences, which create discriminating situations, as one of the informants said:

["... I feel good and happy with friends in the church in this old age. I used to be scolded, discarded, and thrown out of the house for only giving birth to girls. I feel why I didn't convert to Christianity a long time back; life is good here in the church ... "]

[Female, 65 years old]

Gender disparities exist not only in social positions but are also prevalent in other aspects such as educational, employment, and social engagements within the Nepalese Hindu community, as one informant said:

[ ... When I was a Hindu, I was just a daughter-in-law in the family undertaking household chores. Once we converted to Christianity, I learned to read and write, and my daughter is attending a bible college. I also got a peon job in an office because I learned to read and write, which was possible through the church community; and no more abuse by husband... ]

[Dalit Female, 45 years old]

Derné (2012) made similar arguments, stating that the Hindu religion has given a subordinate social status for women but a dominating and ruling social status for men. She further argued that religions such as Christianity and Buddhism mostly provide equal social status for women.

\subsection{Economic and Educational Support}

Religion guides the development and sustenance of culture and traditions, which in turn provide a framework for the development of social, economic, and political institutions. Such institutions offer unique sets of belief systems for economic prosperity and social development (Grier 1997; Iyer 2010). Hindus also make offerings and donations including gold, cows, grains, money, and clothes during the religious ceremony (karma $k a n d a)$. However, they are done in the name of god for the achievement of self-religious gratification and fulfilment of their ancestral religious wishes.

[ ... Before conversion to Christianity, we had to give so much donation to the Priests, who was the only beneficiary, and the community, did not get any benefit from such donations. Donations and offerings were made to make our dead ancestors happy ... ]

[Dalit Male, 36 years old]

A significant number of respondents mentioned that Christianity provides greater emphasis on collective human welfare irrespective of people's backgrounds. This is mainly because of the nonhierarchical modus operandi of Christianity as opposed to the superimposed caste and gender hierarchy embedded within the Hindu religion, as one informant said:

[ ... Whatever funding is raised through donations is used for management of the church. The church committee also used provided loans to do things like celebrating festivals and starting up small businesses. This is such a necessary and useful funding for us ... ]

[Dalit Male, 45 years old]

A greater emphasis on the pursuit of collective welfare within the Christian community has meant that altruism for the pursuit of collective welfare including social welfare and economic progress is much higher in Christianity compared to other religions (Grant 2000). For example, most of the altruistic behaviours amongst the Hindus are primarily carried out to gain the religious gratification of individuals and their families rather than pursuing collective communal gratification. However, the contrary applies to Christianity, as another informant said: 
[ ... We were just Dalits for this Hindu society. Once I converted to Christianity, I developed friendship and family ties with other Christians. Just a few days ago my daughter had a coffee bean stuck in her ear, and one of the churchgoers supported her treatment... ]

[Dalit Female, 45 years old]

\subsubsection{Muthi Daan}

Daan (donation) refers to the practice of giving materials and money to someone without expecting anything in return. Whilst the practices of offering daans are prevalent both in Hinduism and Christianity, the daans offered to religious institutions such as the temples are mainly for the priests belonging to higher non-Dalit castes, indicating an acceptance of caste system and Dalits' binding to the obligations towards the caste system. However, in churches, people make a monetary donation but not material things in a closed fist called the Muthi Daan. One of the interesting things about the Muthi Daan is that neither the pastor announces the amount to be donated nor the people declare the amount donated, but donations are made voluntarily. The practice of Muthi daan is a practice of making small and regular donations to the church to cover the essential costs of the church activities. One of the informants said:

[ . . people don't need to donate; they can donate whatever they can. We don't mind if people do not donate this time; they can always donate next time when we meet up on Saturday... ]

[Dalit Male, 25 years old]

In this practice, the pastor or the senior female leader (guru aama) announces the church attendees to make voluntary monetary donations. In order to collect the donations, the collector goes around the congregation with a collection bag, and people make undisclosed monetary donations. It should be mentioned that the idea of Muthi Daan is not only voluntary but progressive in this implementation, as the church service attendants are expected to make donations according to their circumstances to demonstrate that they are willing to share socioeconomic responsibilities for the benefit of their fellow Christians and the church community.

[ ... We just get some money whatever we get out from our pocket. We don't complain and ask for some of that money if they are making a small contribution. We do not have any children, and we feel happy to be able to support children in the church through donations. It's good to give to other people, isn't it?...]

[Dalit Female, 46 years old]

The advantages are a voluntary, progressive, and flexible mechanism and how it does not put people under any kind of pressure to donate. It is a small amount of money being collected as a process of sharing economic responsibility amongst the Christians regularly.

\subsubsection{Dash Daan}

Similar to Muthi daan the Christian community in the research area also made another flat rate contribution for communal benefit, which is called the Dash Daan. The concept of Dash Daan refers to the practice of making voluntary donations of 10 per cent of their annual salary by every churchgoer for the support of other fellow Christians. The idea of such a flat rate of contribution was considered to be fair by many Christians who participated in this research, as one of the informants said:

[ ... I feel when I donate about 10 per cent of my salary because I know for the fact that this money will be very useful for our own community. This funding will enable to change people for better... ]

[Dalit Male, 30 years old]

In addition to supporting fellow Christians, the practice of Dash Daan also provides funds for logistic support to the organization of church activities including purchasing 
musical instruments, support for youths and children, and other activities on an ad hoc basis. Generally, the common practice within the local churches demonstrated that the pastors of the local churches acknowledge and thank the individuals who donated at the end of the congregation, as one participant said:

[ ... I found it very difficult to raise my children after the death of my husband. I am not very well, and I keep falling ill, and I cannot work as a labourer. I received some seed funding from the cchurch for goat farming. I was given a goat too. I am raising some pigs, goats, and chickens now. I have decent money. I have started to repay the loan on installments ... ]

[Dalit Female, 53 years old]

\subsubsection{Educational Support}

Historically, Christian missionaries travelled to many developing countries with the pretext of spreading education (Blumenfeld 2006; Roy 2008; Boerema 2011). A large number of countries around the world made significant progress in the education sector after the arrival of Christian missionaries, mainly because Christianity promoted educational values and its contribution to the development and human welfare. The contribution of Christianity in the education sector is well documented globally, for example, in African countries such as Tanzania (Mushi 2009), Kenya, and Uganda (Hofer 2003). Similar studies in Asian countries such as India (Ingham 1956; Frykenberg 2008), Nepal and Sri Lanka (Ullrich 2019), and the Philippines (Gutiérrez 2009) and Latin American countries such as Nicaragua (Dodson and O'Shaughnessy 2000) and Ecuador (Kurian 2012) show links between education and Christian missionaries.

Similar to other parts of the world, Nepal has made notable progress in school education after the arrival of Christian missionaries. For example, Christian missionaries established schools like St. Xavier's and St. Mary's in Kathmandu, Gandaki Boarding School in Pokhara, and Amar Jyoti Higher School in Luintel in Gorkha District. These schools are particularly known for creating a friendly and competitive environment for education, especially amongst the disadvantaged caste groups such as Dalits. The importance of the work of church groups in fostering educational opportunity is expressed by one of the informants:

[ ... I even could not study during my childhood. I went to school, but I was not allowed to enter inside the classroom because of being a Dalit. I had to remain outside the classroom and clean the school premises instead. Upon conversion to Christianity, I could attend teaching in the church every morning. I can read the holy bible comfortably now. Even my grandson is also studying staying in the church hostel. They have told us that we can attend a bible college next year... ]

[Dalit Male, 60 years old]

Although the government has made it mandatory for parents to send their children to school up to primary level and education up to secondary level for free, a high proportion of Hindu Dalit children either do not complete primary education or have a high dropout rate at the secondary school level (Sob 2012). However, it is rare for Dalit children from those families who have converted to Christianity to not complete primary education. As education is highly regarded within Christianity, children from Christian Dalit families attend church groups, read the bible, and learn prayer songs. These all contribute to their confidence and educational achievement, as one participant said:

[ ... I was a local shaman in the village and was always interested in studying books. I got many religious books from Varanasi, and I used to read those books, hiding to avoid detection from the Brahmins. I was fluent in many religious texts. Once I converted to Christianity, I was able to study freely, and now I am also fluent in the holy bible. I can even translate and preach the holy bible to other people ... ]

[Dalit Male, 61 years old] 
As such, church groups and Christian missionaries organize a range of educational activities such as bible reading, children's storytelling, and adult literacy to foster a culture of learning for its followers (Elias 2002). Furthermore, they also support children to complete their formal education through creating opportunities for those people who are in need or those who are backward in society (Bhattachan and Pyakuryal 1996). The positive impact of educational achievements supported by Christianity is as one of the participants said:

[ ... Before converting to Christianity, they used to say that a son of a cobbler cannot study, but instead I will become a ploughman. We were also poor and did not have much support, which is why our study suffered a lot. But, once we converted to Christianity we received a lot of encouragement and financial support from the church group. Therefore, our study slowly improved, and I completed my master's degree. I work as a professional now ... ]

[Dalit Male, 37 years old]

The practice of providing such scholarships started a few centuries ago in the Christianitydominated western world, especially through the Christian Missionary Foundations, which helped thousands of Christian as well as non-Christian students gain a college education. In addition to supporting schools, the local Christian church also provided for new converts to attend bible colleges, as another participant said:

[ ... After completing college education, I have been given the opportunity to attend a Bible college with all the facilities. And, I work as a gospel outreach officer in Ghorahi area... ]

[Dalit Male, 26 years old]

As mentioned previously, education is considered a fundamental right of every single individual; historically, Dalits were not allowed to enter the school, making access to education virtually impossible for Dalits. This is because they were told that education was not for the Dalits, as they were born to provide services to non-Dalit caste groups, and attending school was considered to be a crime and unholy for Dalits. Lack of education has meant that Dalits were mostly illiterate, lacked skills for formal employment, and were compelled to take low-paid menial jobs.

\subsection{Meeting Social, Emotional, and Spiritual Needs}

As people grow old, their priorities shift to religious and spiritual enrichment, which are influenced by religious beliefs, values, and lifestyles (Wilkinson and Coleman 2010). As such, elderly people often seek to achieve spiritual satisfaction and welfare needs by getting involved in religious and spiritual activities. Local social and economic institutions and resources are needed to meet those needs (Idler 2008). Religious places, spiritual books, and like-minded friends play an important role in providing peace, and tranquil and safe places such as tea shops, resting places (chautara), temples, and parks are preferred by older people, where they discuss issues of social importance. Hodge et al. (2010) concurs with such eastern philosophy and examines the potential role of religion as a resource for providing welfare services for older people, which were also echoed by many participants in this research, as one said:

[... I realised the benefit of spirituality and religious faith after retirement. After I started working for the local community as a President of the local temple management committee, we chant hymns, sing religious bhajan, which brings many elderly people together... ]

[Dalit Male, 63 years old]

The existence of a superimposed hierarchical caste-based social structure has meant that the older people from higher castes such as Brahmins and Chhetris have greater access to social spaces such as temples and meeting places, where they chant hymns and sing holy songs (bhajan-kirtan) for spiritual and emotional enrichment. Elderly people should 
be treated with respect and dignity, as a lack of a dignified life negatively affects both physical and mental health (Singer and Erickson 2013; Goosby et al. 2018). As elderly Hindu Dalits endured a multitude of discriminatory practices both in private and public spheres, they perceived Christianity to be accommodative, nondiscriminatory, and tolerant. The view expressed by one respondent is a testimony to the experience of elderly Dalits upon conversion into Christianity, as she powerfully posited:

[... I feel satisfied and peaceful being a Christian, and sometimes I become very emotional during prayers. I share all my thoughts and feelings; I forget all my sorrows and troubles. I experience happiness deep inside me right from the soul with the god; I feel so relieved ...]

[Dalit Female, 55 years old]

In Nepal, many elderly people are also worried about their care needs, economic support, death, and funerals. Many elderly Dalits, especially elderly women, experience worry about emotional, economical, and after-death religious performance (kaaj kriya). The rising costs of elderly care have meant that often many Hindu elderly people are being increasingly left in religious premises without adequate support. However, the support that Christianity provided to elderly people, especially during the funerals through local church groups, was highly valued by elderly Christians, as one participant said:

[ ... Children these days rather leave their elderly parents at the Pashupatinath temple because they take it so difficult to support them when they are alive and it's hard for them to perform the last rituals when they die. Christian people do not have to worry about all these, as our funerals are organized by our local church ... ]

[Dalit Female, 45 years old]

Unlike Hinduism, Christianity, on the other hand, provides public spaces and inclusive attitudes and behaviours for all elderly people irrespective of their caste affiliation. Such an inclusive approach adopted by Christianity enabled elderly people to share their experiences and contribute to the discussion on a range of local issues and national politics in a safe environment. Whilst elderly Dalits faced discrimination in pursuit of their spiritual desires in religious institutions such as temples and holy places, they were heartily welcomed in the Christian communities and the church groups.

\subsection{Medical Support and Healings}

Recognizing the need for health facilities, especially in rural areas, many Christian organizations and church groups have implemented a range of educational and health projects. Such projects have proven to be extremely beneficial to local communities, as one of the informants said:

[ ... We are Dalits, and on top of that I had leprosy. I was taken out of the village due to social taboos attached to leprosy. We had a tough time in those days. I was admitted to a mission hospital in Ghorahi, where I received all the treatments. My son was good at his study, and he was taken to Kathmandu to study medicine by a pastor. He works as a medical doctor in Kathmandu these days ... ]

[Dalit Female, 66 years old]

Furthermore, the ideas of healing and traditional medical practices are prevalent in almost all societies around the world (McGuire 1996; Doron and Broom 2013). Such religious and spiritual beliefs are prevalent within various communities following different religions in Nepal. For example, the Lamas (spiritual leaders) perform many spiritual and healing practices amongst the Mongolians whilst Jhakirs and Gurus do the same within the Newar communities in Nepal. Evidence both from Nepal and elsewhere in the world suggests that many people have converted to Christianity for healing as well as for better opportunities in society (Kehrberg 2000). One of the informants said that:

[ ... I did all the medication, and there is hardly any hospital where I did not attend. I was treated by shamans and done all sorts. But I still didn't feel well. One of the local 
sisters prayed for me at the church and I felt good about it. We attend church together and I began to feel better gradually. I have no longer illness these days ... ]

[Dalit Female, 44 years old]

Kirchheiner (2016) argues that most of the Dalits and Magars in Nepal are converting themselves from Hinduism to Christianity for healing and a range of other opportunities within Christianity as opposed to Hinduism. Such benefits including different prayers, medical care through different organizations like Christians against Tuberculosis (CATS) for tuberculosis treatments, various mission hospitals (for skin diseases, orthopaedics, and leprosy), and other financial support are provided to the people who are in need. One of the informants said that:

[ ... I was almost dead that day, really, if our local pastor had not taken me to the CATS office. I had tuberculosis, but no one had a clue about it. I had a bad chesty cough when I was at the church. I was advised by him to attend the CATS office where they not only gave medicine but also provided all the necessary food and vitamins. I recovered quickly from tuberculosis... ]

[Dalit Male, 58 years old]

It could be argued that cultural beliefs, traditions, and values play an important role in many aspects of human society in Nepal. As such, many people still believe that attendance to the church and surrendering to the mercy of Jesus Christ supports them to overcome long-term health problems and individual and family difficulties. Such belief was strongly held by many people who converted to Christianity, whereas their experience whilst they were Hindus was characterized by discrimination, exclusion and religious rigidity, and cultural inflexibility.

A summary of the key research findings and discussions presented in Figure 2 indicates a two very different realms of individual and societal life experiences of Hindu Dalits in Nepal before and after their conversion to Christianity. The analysis here clearly suggests that, for the Dalits, the world of Hinduism is characterized by regressive institutions, policies, and processes that are deeply embedded in all aspects of governance including the state, society, religious institutions (temples), and religious leaders (priests), underpinned by a rigid and regressive caste system. A systematically exclusionary treatment of Dalits in Hinduism has meant that their life experiences were severely constrained. This research has identified a range of regressive factors within the Hindu society in Nepal that contributed towards Dalits' conversion to Christianity. Numerous religious practices were explicitly based on orthodoxy Hinduism with very little scientific basis and were blindly imposed on Hindus, especially the Dalits. The nonegalitarian religious regime of Hinduism systematically discriminated against and excluded Dalits from almost all aspects of human life in Nepal. Such a systematic exclusion and discrimination and a distinct lack of targeted welfare support for youths, elderly, women, and girls rendered Dalits into entrenched poverty and inequalities. The cumulative effect of these regressive elements within Hinduism acted as the push factors of Dalits' conversion to Christianity.

Contrary to the world of Hinduism, the world of Christianity is characterized by more egalitarian and inclusive institutions, policies, and processes, which are deeply embedded in all aspects of governance including community, religious institutions (churches and missionaries), and religious leaders (pastors), shaped by the progressive casteless system. Unlike in Hinduism, Dalits were treated progressively in Christianity, providing them a sense of freedom and liberation. A range of progressive factors ingrained within Christianity in Nepal attracted Nepalese Dalits towards Christianity. Both the review of the secondary data and analysis of the primary data indicated that the religious practices in Christianity were explicitly based on pragmatic or nonorthodoxy understanding. Such practices catered a greater degree of flexibility for the followers of Christianity, especially the Dalits. The egalitarian religious regime of Christianity was considered to be inclusive and nondiscriminatory by Dalits in many aspects of their life in Nepal. Such systematically progressive and nondiscriminatory practices within Christianity provided more targeted 
welfare supports for youths, the elderly, and women and girls, enabling them to overcome poverty, marginalisation, and inequalities.

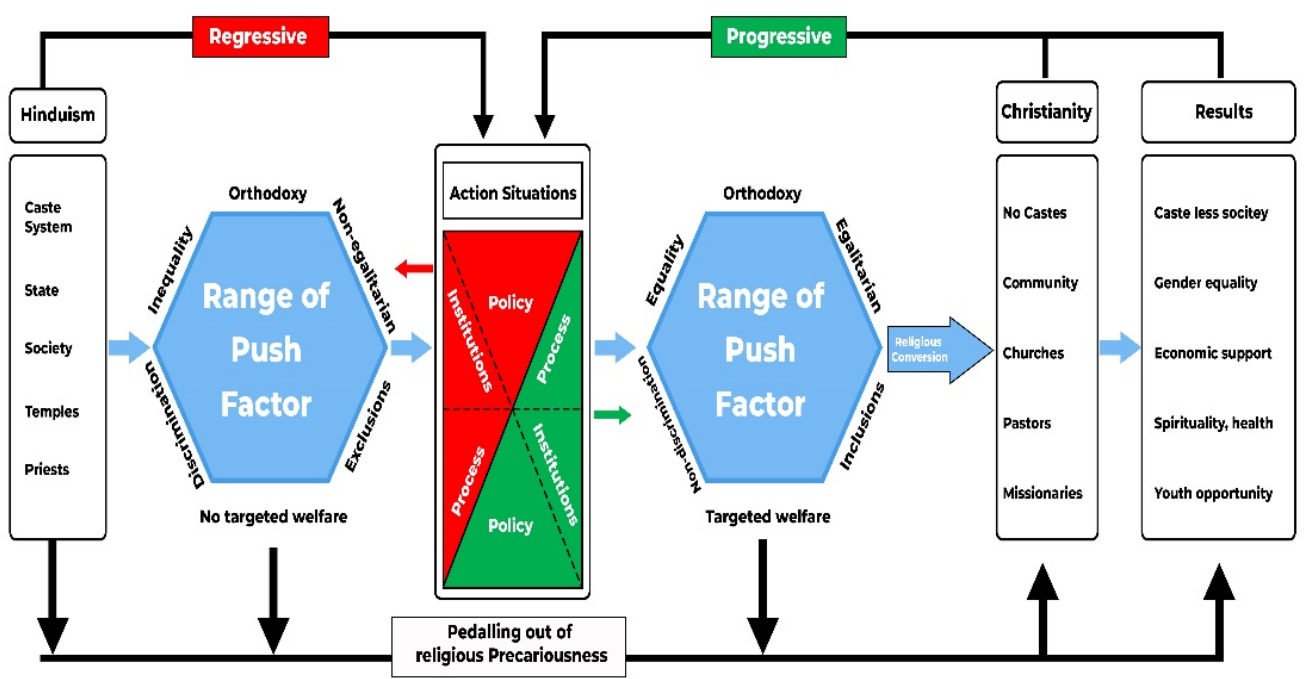

Figure 2. Summary of the Findings.

\section{Conclusions}

The findings from this research indicate that the process of religious conversion of Hindu Dalits to Christianity is much more than just the economic benefits accrued to them. Dalits in Nepal have endured rather regressive sociopolitical institutions, which are underpinned by a rigid orthodox and dogmatic caste system characterised by discrimination, exclusions, denial, and untouchability constraining their life experiences, dehumanizing them, and reducing their welfare. Such a systematic exclusion and discrimination and a distinct lack of targeted welfare support for youth, elderly, women, and girls rendered Dalits into poverty and inequalities. The cumulative effect of these regressive elements within Hinduism acted as push factors in Dalits' conversion to Christianity. However, the Dalits who converted to Christianity believed that the Christian faith was characterized by a casteless system and nondiscriminatory, inclusive, and egalitarian practices. Unlike in Hinduism, Dalits experienced a sense of freedom and liberation after being converted to Christianity. Such systematically progressive and nondiscriminatory practices within the Christianity provided more targeted welfare supports for youths, the elderly, and women and girls, enabling them to overcome poverty and inequalities. The cumulative effect of these progressive elements within Christianity acted as the pull factors in Dalits' conversion to Christianity.

It could be argued that the dominant narratives of proselytization presented mainly by non-Dalits higher castes and their institutions within the Hinduism has little intellectual and practical relevance, as the evidence here suggests that neither were the converts enticed by the promise of economic prosperity nor have those newly converted Dalit Christians improved their economic status as a result of the conversion to Christianity. Evidence from this research has revealed that the key reasons for a disproportionately high rate of Christian conversion amongst the Dalits are muticausal and flexible personal and sociocultural, but not in the sense that the missionaries leverage them, rather in the sense that the newly converted Dalit Christians recognize them as a valuable sources of conversion justification. Therefore, Hinduism should rather reform itself by eradicating caste-based discrimination and implementing inclusive and egalitarian institutions and policies to make it more relevant to everyday life of both the Dalits and non-Dalits alike in order to reduce a mass exodus of Hindu Dalits' conversion to Christianity. 
Author Contributions: Conceptualization, B.P.; methodology, S.C.; software, R.B.; validation, B.P., S.C., S.T.M., R.B.; formal analysis, B.P., S.C.; investigation, B.P.; resources, B.P.; data curation, S.C.; writing-original draft preparation, B.P.; writing—review and editing, B.P. and R.B.; visualization, R.B.; supervision, S.T.M.; project administration, S.C. All authors have read and agreed to the published version of the manuscript.

Funding: This research received no external funding.

Institutional Review Board Statement: The study was conducted according to the guidelines of the Declaration of Helsinki, and approved by the Institutional Review Board (or Ethics Committee) of the Department of Anthropology, Tribhuvan University (protocol code: TU- ANTHO-BNKS-BP365C and Date of approval: 12 February 2018).

Informed Consent Statement: Informed consent was obtained from all subjects involved in the study.

Data Availability Statement: Data reported in this research can be found at the Departmental Library, Department of Anthropology, Tribhuvan University, Kirtipur, Nepal.

Conflicts of Interest: The authors declare no conflict of interest.

\section{References}

Alsop, Ian. 1996. Christians at the Malla Court: The Capuchin 'piccolo libro'. In Change and Continuity: Studies in the Nepalese Culture of the Kathmandu Valley. Edited by Siegfried Lienhard. Torino: CESMEO, pp. 123-35.

Anderson, Allan. 2004. Pentecostalism in Africa: An overview. ORITA: Ibadan Journal of Religious Studies 36: 38-56.

Apichella, Michael. 1996. Prison Pentecost. Eastbourne: Kingsway Publications.

Bankston, William B., Craig J. Forsyth, and H. Hugh Floyd. 1981. Toward a general model of the process of radical conversion: An interactionist perspective on the transformation of self-identity. Qualitative Sociology 4: 279-97. [CrossRef]

Barclay, John. 2009. The Church in Nepal: Analysis of its Gestation and growth. International Bulletin of Missionary Research 33: 189-94. [CrossRef]

Barker, Eileen. 1984. The Making of a Moonie. Oxford: Blackwell Publication.

Bawa, Sylvia. 2019. Christianity, tradition, and gender inequality in postcolonial Ghana. African Geographical Review 38: 54-66. [CrossRef]

Beckford, James A. 1997. The Transmission of Religion in Prison, Recherche. Sociologiques 28: 101-12.

Beidelman, Thomas O. 1982. Colonial Evangelism: A Socio-Historical Study of an East African Mission at the Grassroots. Bloomington: Indiana University Press.

Bennett, Lynn. 1985. Dangerous wives and sacred sisters: Social and symbolic roles of high-caste women in Nepal. Religious Studies 21: 246-50.

Bhattachan, Krishna B., and Kailas N. Pyakuryal. 1996. The issue of national integration in Nepal: An ethnoregional approach. Occasional Papers in Sociology' and Anthropology 5: 17-38. [CrossRef]

Bhattachan, Krishna B., Kamala Hemchuri, Yogendra Gurung, and Charkra Man Biswakarma. 2003. Existing Practices of Caste-Based Untouchability in Nepal and Strategy for a Campaign for Its Elimination. Kathmandu: ActionAid Nepal.

Bishwakarma, Padmalal. 2004. The situation analysis for dalit women of Nepal. Paper presented at the National Seminar on Raising Dalit Participation in Governance Centre for Economic and Technical Studies, Lalitpur, Nepal, May 3-4; Kathmandu: Economic and Technical Studies in Cooperation Friedrich-Ebert-Stiftung.

Blumenfeld, Warren J. 2006. Christian privilege and the promotion of "secular" and not-so "secular" mainline Christianity in public schooling and in the larger society. Equity \& Excellence in Education 39: 195-210.

Boerema, Albert J. 2011. A Research Agenda for Christian Schools. Journal of Research on Christian Education 20: 28-45. [CrossRef]

Cameron, Mary M. 1998. On the Edge of the Auspicious: Gender and Caste in Nepal. Chicago: University of Illinois Press.

Campbell, Ben. 2016. Tamang Christians and the Resituating of Religious Difference. In Religion, Secularism, and Ethnicity in Contemporary Nepal, 1st ed. Edited by David N. Gellner, Sondra L. Hausner and Chiara Letizia. Oxford: Oxford University Press, pp. 403-27.

Cartledge, Mark J. 2013. Pentecostal healing as an expression of godly love: An empirical study. Mental Health, Religion $\mathcal{E}$ Culture 16: 501-22.

Central Bureau of Statistics. 2001. Census Report, Nepal; Kathmandu: Central Bureau of Statistics.

Central Bureau of Statistics. 2011. Census Report, Nepal; Kathmandu: Central Bureau of Statistics.

Cruz, Joel Morales. 2014. The Histories of the Latin American Church: A Handbook. Minneapolis: Augsburg Fortress Publishers.

DDC. 2018. District Profile of Dang District. Ghorahi: District Development Committee, Dang.

Derné, Steve. 2012. Men's sexuality and women's subordination in Indian nationalisms. In Gender Ironies of Nationalism. London: Routledge, pp. 251-74. 
Dhakal, Kamal. 2014. Conversion into Christianity in Nepal: A Way to Break Down the Social and Cultural Hierarchy. Master's thesis, The University of Stavanger, Stavanger, Norway.

Dodson, Michael, and Laura Nuzzi O'Shaughnessy. 2000. Nicaragua's Other Revolution: Religious Faith and Political Struggle. Chapel Hill: University of North Carolina Press.

Doja, Albert. 2000. The politics of religion in the reconstruction of identities: The Albanian situation. Critique of Anthropology 20: 421-38. [CrossRef]

Doron, Assa, and Alex Broom. 2013. Health, Culture and Religion in South Asia: Critical Perspectives. London: Routledge.

Dumont, Louis. 1980. Homo Hierarchicus: The Caste System and Its Implications. Chicago: University of Chicago Press.

Elias, John L. 2002. A History of Christian Education: Protestant, Catholic, and Orthodox Perspectives. Malabar: Krieger Publishing Company.

Eriksen, Annelin. 2012. The pastor and the prophetess: An analysis of gender and Christianity in Vanuatu. Journal of the Royal Anthropological Institute 18: 103-22. [CrossRef]

Falla, Ricardo. 2001. Quiché Rebelde: Religious Conversion, Politics, and Ethnic Identity in Guatemala. Austin: University of Texas Press.

Fernandes, Leela. 2011. Unsettled territories: State, civil society, and the politics of religious conversion in India. Politics and Religion 4: 108-35. [CrossRef]

Flemming, Leslie A. 2019. Women's Work for Women: Missionaries and Social Change in Asia. London: Routledge.

FNCN. 2012. Christian population below actual size. Kathmandu Post. December 6. Available online: https://kathmandupost.com/ news / 2012-12-05/fncn-christian-population-below-actual-size.html (accessed on 16 June 2020).

Foddy, William, and William H. Foddy. 1994. Constructing Questions for Interviews and Questionnaires: Theory and Practice in Social Research. Cambridge: Cambridge University Press.

Foucault, Michael. 2002. The Order of Things. An Archaeology of the Human Sciences. London: Routledge.

Fountain, Philip. 2015. Proselytizing development. In The Routledge Handbook of Religions and Global Development. London: Routledge, pp. 94-112.

Fricke, Tom. 2008. Tamang conversions: Culture, politics, and the Christian conversion narrative in Nepal. Journal of Centre for Nepal and Asian Studies 35: 35-63.

Frykenberg, Robert Eric. 2008. Christianity in India: From Beginnings to the Present. London: Oxford University Press.

Gellner, David N. 2007. Caste, ethnicity and inequality in Nepal. Economic and Political Weekly 42: 1823-28.

Ghorahi Municipality. 2018. Annual Publication of Ghorahi Sub-Metropolitan Municipality. Ghorahi: Ghorahi Sub-Metropolitan Municipality Press.

Gibson, Ian. 2019. Praying for Peace: Family Experiences of Christian Conversion in Bhaktapur. HIMALAYA, the Journal of the Association for Nepal and Himalayan Studies 39: 53-68.

Goffman, Erving. 1968. Asylums: Essays on the Social Situation of Mental Patients and Other Inmates. Piscataway: AldineTransaction.

Goosby, Bridget J., Jacob E. Cheadle, and Colter Mitchell. 2018. Stress-related biosocial mechanisms of discrimination and African American health inequities. Annual Review of Sociology 44: 319-40. [CrossRef]

Gordon-Conwell Theological Seminary. 2013. Christianity in Its Global Context, 1970-2020: Society, Religion and Mission. South Hamilton: Center for the Study of Global Christianity. Available online: https: / web.archive.org/web/20180922211444/https: //www.gordonconwell.edu/ockenga/research/documents/ChristianityinitsGlobalContext.pdf (accessed on 16 June 2020).

Grant, Colin. 2000. Altruism and Christian Ethics 18. London: Cambridge University Press.

Greil, Arthur L., and David R. Rudy. 1983. Conversion to the world view of Alcoholics Anonymous: A refinement of conversion theory. Qualitative Sociology 6: 5-28. [CrossRef]

Grier, Robin. 1997. The effect of religion on economic development: A cross national study of 63 former colonies. Kyklos 50: 47-62. [CrossRef]

Griffiths, Michael. 2003. Previous Convictions: Conversion in the Present Day. Evangelical Quarterly: An International Review of Bible and Theology 75: 91-92. [CrossRef]

Grudem, Wayne. 1994. An Introduction to Biblical Doctrine: Systematic Theology. Grand Rapids: Zondervan.

Gutiérrez, Angelina L. 2009. The preferential option for the poor in Catholic education in the Philippines: A report on progress and problems. International Studies in Catholic Education 1: 135-51.

Hakim, Catherine. 2000. Research Design: Successful Designs for Social and Economic Research, 2nd ed. London: Routledge.

Heffernan, Anne. 2019. Student/teachers from Turfloop: The propagation of Black Consciousness in South African schools, $1972-76$. Africa 89: 189-209. [CrossRef]

Hindmarsh, Bruce. 2014. Religious Conversion as Narrative and Autobiography. In The Oxford Handbook of Religious Conversion. Edited by Lewis R. Rambo and Charles E. Farhadian. Oxford: Oxford University Press.

Hodge, David R., Robin P. Bonifas, and Rita Jing-Ann Chou. 2010. Spirituality and older adults: Ethical guidelines to enhance service provision. Advances in Social Work 11: 1-16. [CrossRef]

Hofer, Katharina. 2003. The role of evangelical NGOs in international development: A comparative case study of Kenya and Uganda. Africa Spectrum 375-98.

Hood, Ralph W., Jr., Peter C. Hill, and Bernard Spilka. 2018. The Psychology of Religion: An Empirical Approach, 5th ed. New York: Guilford Publications.

Idler, Ellen. 2008. The psychological and physical benefits of spiritual/religious practices. Spirituality in Higher Education Nezwsletter 4: $1-5$. 
Ingham, Kenneth. 1956. Reformers in India 1793-833: An Account of the Work of Christian Missionaries on Behalf of Social Reform. Cambridge: Cambridge University Press.

Iyer, Sriya. 2010. Religion and economic development. In Economic Growth. London: Palgrave Macmillan, pp. 222-28.

Jindra, Ines W. 2014. A New Model of Religious Conversion: Beyond Network Theory and Social Constructivism. Leiden: Brill Publications.

Kehrberg, Norma. 2000. The Cross in the Land of the Khukuri. Kathmandu: Ekta Books.

Kharel, Sambriddhi. 2010. The Dialectics of Identity and Resistance among Dalits in Nepal. Ph.D. thesis, University of Pittsburgh, Pennsylvania, PA, USA.

Kirchheiner, Ole. 2016. Culture and Christianity Negotiated in Hindu Society: A Case Study of a Church in Central and Western Nepal. Doctoral dissertation, Middlesex University, London, UK.

Kisan, Yam B. 2005. The Nepali Dalit Social Movement. Kathmandu: Legal Rights Protection Society.

Klingorova, Kamila, and Tomáš Havlíček. 2015. Religion and gender inequality: The status of women in the societies of world religions. Moravian Geographical Reports Moravian Geographical Reports 23: 2-11. [CrossRef]

Krippendorff, Klau. 2018. Content Analysis: An Introduction to Its Methodology, 2nd ed. Thousand Oaks: Sage Publication.

Krueger, Richard A. 2014. Focus Groups: A Practical Guide for Applied Research. Newbury Park: Sage Publications.

Kurian, George Thomas. 2012. Ecuadorian Christianity. In The Encyclopaedia of Christian Civilization. London: Wiley Online Library.

Lamb, Christopher, and M. Darroll Bryant. 1999. Religious Conversion: Contemporary Practices and Controversies. London: Bloomsbury Publishing.

Landon, Perceval. 1928. Nepal. London: Constable and Co., vol. 2, p. 236.

Lawoti, Mahendra. 2005. Towards a Democratic Nepal: Inclusive Political Institutions for a Multicultural Society. Delhi: Sage.

Lawoti, Mahendra, and Susan Hangen. 2013. Nationalism and Ethnic Conflict in Nepal: Identities and Mobilization after 1990. London: Routledge.

Letizia, Chiara. 2012. Shaping secularism in Nepal. European Bulletin of Himalayan Research 39: 66-104.

Lofland, John, and Rodney Stark. 1965. Becoming a world saver: A theory of conversion to a deviant perspective. American Sociological Review 30: 862-75. [CrossRef] [PubMed]

Long, Theodore E., and Jeffrey K. Hadden. 1983. Religious Conversion and the Concept of Socialisation: Integrating the Brainwashing and Drift Models. Journal for the Scientific Study of Religion 22: 1-14. [CrossRef]

Lorenzen, David N. 2003. Europeans in late Mughal south Asia: The perceptions of Italian missionaries. The Indian Economic E Social History Review 40: 1-31.

Maruna, Shadd, Louise Wilson, and Kathryn Curran. 2006. Why God is often found behind bars: Prison conversions and the crisis of self-narrative. Research in Human Development 3: 161-84. [CrossRef]

McCullough, Michael E., and Brian L. B. Willoughby. 2009. Religion, self-regulation, and self-control: Associations, explanations, and implications. Psychological Bulletin 135: 1-26. [CrossRef] [PubMed]

McGrath, Alister E. 2012. Mere Apologetics: How to Help Seekers and Skeptics Find Faith. London: Baker Books.

McGuire, Meredith B. 1996. Religion and healing the mind/body/self. Social Compass 43: 101-16. [CrossRef]

Mead, George Herbert. 1967. Mind, Self and Society. Chicago: University of Chicago Press.

Mushi, Philemon Andrew K. 2009. History and Development of Education in Tanzania. African books collective. Chapel Hill: North Carolina Press.

Newton, Taylor, and Daniel McIntosh. 2013. Unique Contributions of Religion toMeaning. In The Experience of Meaning in Life: Classical Perspectives, Emerging Themes, and Controversies. Edited by Joshua A. Hicks and Clay Routledge. Dordrecht, Heidelberg and New York: Springer, pp. 257-70.

Oviedo, Lluis. 2019. Meaning and Religion: Exploring Mutual Implications. Scientia et Fides 7: 25-46. [CrossRef]

Paloutzian, Raymond F., James T. Richardson, and Lewis R. Rambo. 1999. Religious conversion and personality change. Journal of Personality 67: 1047-79. [CrossRef]

Parajuli, Biswo Kallyan. 2007. Occupational change among the Gaines of Pokhara City. In Nepalis Inside and Outside Nepal. Edited by Ishii Hiroshi, David N. Gellner and Katsuo Nawa. Delhi: Manohar, pp. 59-84.

Pariyar, Bishnu, and Jon C. Lovett. 2016. Dalit identity in urban Pokhara, Nepal. Geoforum 75: 134-47. [CrossRef]

Parrucci, Dennis J. 1968. Religious Conversion: A Theory of Deviant Behavior. Sociology of Religion 29: 144-54. [CrossRef]

Pattison, George. 2018. Covenant, Promise, and the Gift of Time. Religious Inquiries 7: 75-90.

Peace, Richard V. 2004. Conflicting understandings of Christian conversion: A missiological challenge. International Bulletin of Missionary Research 28: 8-14. [CrossRef]

Peck, Dennis L. 1987. Religious Conviction among Non-Parolable Prison Inmates. Corrective and Social Psychiatry and Journal of Behaviour Technology Methods and Therapy 33: 165-74.

Perry, Cindy L. 1990. A Biographical History of the Church in Nepal, 3rd ed. Kathmandu: Nepal Church History Project, pp. 9-35.

Racine, Karen. 2008. Commercial Christianity: The British and Foreign Bible Society's Interest in Spanish America, 1805-1830. Informal Empire in Latin America: Culture, Commerce and Capital 78-98.

Rai, Lagan. 2017. Conversion to Christianity through labour migrant. In Kinship Studies in Nepali Anthropology. Edited by Uprety Laya Prasad, Binod Pokharel and Suresh Dhakal. Kinship Studies in Nepali Anthropology. Kathmandu: Central Department of Anthropology, Tribhuvan University.

Rambo, Lewis R. 1993. Understanding Religious Conversion. New Haven: Yale University Press. 
Richards, Barry. 1978. The Experience of Long-Term Imprisonment-An Exploratory Investigation. British Journal of Criminology 18: 162-69.

Richardson, James T. 1985. The active vs. passive convert: Paradigm conflict in conversion/recruitment research. Journal for the Scientific Study of Religion 1985: 163-79. [CrossRef]

Robinson, Rowena, and Joseph Marianus Kujur, eds. 2010. Margins of Faith: Dalit and Tribal Christianity in India. New Delhi: SAGE Publications India.

Romain, Jonathan A. 2000. Your God Shall Be My God: Religious Conversion in Britain Today. London: SCM Press.

Roy, Don. 2008. Christian schools-a world of difference. TEACH Journal of Christian Education 2: 38-44.

Saiya, Nilay, and Stuti Manchanda. 2020. Anti-conversion laws and violent Christian persecution in the states of India: A quantitative analysis. Ethnicities 20: 587-607. [CrossRef]

Sharma, Bal Krishna. 2001. A history of the Pentecostal movement in Nepal. Asian Journal of Pentecostal Studies 4: $295-305$.

Shellnutt, Kate. 2017. Nepal Criminalizes Christian Conversion and Evangelism. Christianity Today 25. Available on: https: / / runwiththeword.net/wp-content/uploads/2017/11/Nepal-News-Alert.pdf (accessed on 18 June 2021).

Singer, Merrill, and Pamela I. Erickson. 2013. Global Health: An Anthropological Perspective. Long Grove: Waveland Press.

Singer, Margaret Thaler, and Janja Lalich. 1995. Cults in Our Midst. Hoboken: Jossey-Bass/Wiley.

Skotnicki, Andrew. 1996. Religion and Rehabilitation. Criminal Justice Ethics 15: 34-43. [CrossRef]

Snow, David A., and Richard Machalek. 1984. The sociology of conversion. Annual Review of Sociology 10: 167-90. [CrossRef]

Sob, Durga. 2012. The Situation of the Dalits in Nepal Prospects in a New Political Reality. Voice of Dalit. Kathmandu: MD Publication Pvt. Ltd.

Stark, Rodney, and Roger Finke. 2000. Acts of Faith. Berkeley: University of California Press.

Stewart, David W., and Prem N. Shamdasani. 2014. Focus Groups, Theory and Practice. London: Sage Publication.

Stronge, Samantha, Joseph Bulbulia, Don E. Davis, and Chris G. Sibley. 2021. Religion and the development of character: Personality changes before and after religious conversion and deconversion. Social Psychological and Personality Science 12: 801-11. [CrossRef]

Sykes, Gresham M. 2021. The Society of Captives. Princeton: Princeton University Press.

Thumma, Scott. 1991. Seeking to be Converted: An Examination of Recent Conversion Studies and Theories. Pastoral Psycholog 39: 185-94. [CrossRef]

Timor, Un. 1998. Constructing a rehabilitative reality in special religious wards in Israeli prisons. International Journal of Offender Therapy and Comparative Criminology 42: 340-59. [CrossRef]

Travisano, Richard V. 1970. Alternation and conversion as qualitatively different transformations. In Social Psychology Through Symbolic Interaction. Edited by Gregory Prentice Stone and Harvey A. Farberman. Waltham: Ginn-Blaisdell, pp. 594-606.

Turner, Bryan S. 2013. The Religious and the Political: A Comparative Sociology of Religion. Cambridge: Cambridge University Press.

Ullrich, Helen. E. 2019. Discussion and Conclusion Reflections on the Impact of Education in South Asia: From Sri Lanka to Nepal. In The Impact of Education in South Asia. Cham: Palgrave Macmillan, pp. 287-97.

Upadhyay, Prakash. 2020. Restructuring Spiritualism in New Life: Conversion to Christianity in Pokhara, Nepal. Janapriya Journal of Interdisciplinary Studies 9: 135-47. [CrossRef]

United States Department. 2018. 2018 Report on International Religious Freedom: Nepal. United States Department of State. Available online: https: / / www.state.gov/reports / 2018-report-on-international-religious-freedom/nepal/ (accessed on 16 June 2020).

Villa-Vicencio, Charles, and Peter Grassow. 2009. Christianity and the Colonisation of South Africa, 1487-1883: A Documentary History. Pretoria: Unisa Press.

Wankhede, Harish S. 2009. The Political Context of Religious Conversion in Orissa. Economic and Political Weekly 44: 33-38.

Wilkinson, Peter J., and Peter G. Coleman. 2010. Strong beliefs and coping in old age: A case-based comparison of atheism and religious faith. Ageing $\mathcal{E}$ Society 30: 337-61.

Zinnbauer, Brian J., and Kenneth I. Pargament. 1998. Spiritual conversion: A study of religious change among college students. Journal for the Scientific Study of Religion 37: 161-80. [CrossRef] 